\title{
THE SLOWLEY STRUCTURED CLASSROOM: NARRATIVE TIME, LIVED EXPERIENCE AND THE CONTEMPORARY HE CLASSROOM
}

\author{
AMANDA RUSSELL BEATTIE \\ a.r.beattie@aston.ac.uk \\ School of Languages and Social Sciences, \\ Aston University, UK
}

\begin{abstract}
The detrimental impact of a globalised, highly technological world within the academe is well documented. The combination of moral efficiency, the global proliferation of contemporary capitalism and the compressing of time and space all have a role to play in the professional practice of contemporary higher education. This article attends to the negative outcomes of time and professional practice. It suggests the narrative classroom as one means of demonstrating agency and disrupting the status quo design of the higher education establishment. It employs an autoethnographic methodology to preface individual voice cultivated through storytelling and reflexivity. It suggests that this transformative process entails the establishment of creative communities. These communities are, by their very nature, relational and affective - and a necessary component of individual transformation.
\end{abstract}

Keywords: time; agency; professional practice; critical pedagogy

\section{Introduction}

The detrimental impact of a globalised, highly technological world within the academe is well documented. (See for example Giroux 2002; Lunch 2006 \& 2007; Sloan 2008; Patrick 2013; and Hayes and Jandrić 2014.) The critiques focus on the challenges of a neoliberal framing of higher education, and seek to disrupt the comodification of knowledge and the understanding of the student as a consumer therein. This article attends to this state of affairs, paying particular attention to the role that time has played in bringing it about. I suggest, drawing on autoethnographic reflections, the idea of the narrative classroom as one way of disrupting the neoliberal framing of higher education.

The narrative classroom experience reveals how lecturers are agents of change. They are capable of challenging status quo iterations of teaching and learning, 
thereby slowing down the learning journey in the classroom. This framing of the classroom suggests - drawing on insights from narrative theory (Bruner 1991) that a focus on lived experience as a pedagogical tool can slow down the classroom. Storytelling does not follow a linear trajectory. Consequently, the transformative experience fostered by storytelling challenges traditional iterations of time. It suggests a non-linear experience that does not attend to the demands of clock time. In order to support such claims, section one describes the narrative classroom and the added value of subjective methodologies. Part two examines my own teaching and learning reflections and observations acquired during the course of my final year module, Contemporary Political Theory. The final section imagines how this approach might continue to develop and thrive in the future. In making such claims, I am mindful of two inter-related challenges: namely, the lack of engagement from students and the wider fear that reflexive, autobiographical framings of teaching and learning might engender. I address these challenges in the conclusion.

Judith Walker (2009) attends to the challenges that time in a globalised world places on the lived experience of the contemporary academic. She identifies a series of understandings of time. Clock time distinguishes the modern society from its pre-modern counterpart. It highlights the move away from space and nature and the use of lunar cycles - for example, to determine time cycles. The pre-modern interpretation of time displays a symbiotic relationship between society and nature. It suggests a long-term, evolutionary view of the future. Walker notes how some scholars, for example Urry (1994), describe this period as glacial or timeless. Clock time removes this slowing down and challenges the symbiosis of nature and society. Instead, time - and the influence of capitalist modes of production - is increasingly associated with moral efficiency. Individuals must master time. They are no longer simply 'in' time. Walker goes on to distinguish global time from this interpretation of clock time. She suggests that capitalism's transformation of the global sphere, combined with newly emerging technologies, has contributed to a compression of time. This has rendered individuals powerless and anxious as they seek to manage their lived experience aware of the ongoing pressure to master time. Such mastery is revealed in academics' ongoing output of scholarly articles and acquisition of research income while attending to their teaching responsibilities. Failure to demonstrate these goals, she argues, is evidence of academic failure.

I suggest that the academic's creative potential is also being silenced as demands for mastery remain unchecked. Roxanne Lynne Doty (2004) argues in her interrogation of the academic voice that ideas and innovation do not guide the mastery outlined by Walker (2009). Rather, academics now manage their career attuned to the needs and structural requirements of tenure. With this in mind, I want, in this article, to draw the focus towards another particular aspect of our shared professional practice. I wonder what implications this speeding up of time, and the demands of research excellence, has on the professional practice within the 
classroom? I suggest that the classroom is a political space within which academics can exert a degree of agency, challenging the unfolding expectations of time, control and subject mastery. This agency begins by attending to the personal and challenging patriarchal iterations of teaching and learning. It focuses on the cultivation of personal relationships within the classroom, which, as current research suggests, are critical to the successful university experience. (See for example Chambliss, 2014, and Todd et al., 2006.) I draw on the discourses of critical pedagogy to sustain this idea, and argue on behalf of the creative potential of both lecturers and students. Both the students and the lecturer are understood to be co-producers of knowledge in this experience. They are responsible for the creation of the learning community established through shared autobiographical experiences and enhanced by reflexive practices.

I suggest, drawing on my own teaching and learning practice - herein referred to as professional practice - that this approach facilitates an alternative, slower learning environment. Throughout the article, I offer my experience of developing and practising narrative principles within the formal classroom. I draw on Bartholomew (2015), who suggests that an autoethnographic approach offers beneficial insights to understanding our shared professional practice. I extend his argument and offer this reflexive potential to students as well. This reflexivity allows individuals within the classroom to probe their own identity and authenticity and ponder their agentic capabilities. We can understand this experience as falling broadly within what is now identified as transformative learning. (See for example Taylor \& Cranton 2012.) I suggest such transformations challenge iterations of clock time and upset the pre-eminence of global time.

\section{Narrative Approaches as a Challenge to Time in $\mathrm{HE}$}

Time, in the unfolding of the history of ideas, has been studied by Hutchings (2008). She suggests that the concept of time is portrayed as something to be controlled - it has a predictive quality. She shows in her interrogation of time and political thought that the philosopher enjoys a particular position within this unfolding narrative. The philosopher predicts the future and controls the unfolding of history. It is a privileged position that has allowed for a particular institutional design of the state. ${ }^{1}$ Hutchings's claims are supported by the writings of other contemporary scholars. For example, Hom (2010) documents the relationship of clock time and the unfolding of history. He suggests that institutional practices such as colonialism, the Great War and the effects of post-colonialism contributed to the mutually supportive role of time and the rise of the modern global state. Likewise, McIntosh (2015) discusses the controlling nature of time. He, like Hutchings, notes how time has been harnessed throughout history to control individuals' daily lives. While McIntosh's writings reveal the role of time throughout history, he is likewise critical of the role that time plays in the production of contemporary scholarship. His interrogation of peace research and 
the democratic peace thesis reveals that causal thinking about war - and the ability to predict its occurrence - emphasises universal and general findings to the detriment of a highly nuanced understanding of the wider temporal and spatial roles that time ought to play in the academe.

We can, I suggest, find elements of that controlling element of time in professional practice. Judith Walker's (2009) work on time in higher education provides some insight into its ability to control the life of the lecturer. She suggests that the ability to harness time is one means through which the academic can demonstrate a mastery of her subject. The good academic is the fruitful academic who publishes, attends conferences and acquires grants. This is very similar to the historical work on time produced by Hom (2010), who looks to the evolutionary development of monasteries and suggests that the good monk - like the contemporary academic - was judged on his ability to efficiently negotiate the demands of time by carving out appropriate space for both prayer and the everyday tasks. But there is more to be said about the controlling aspect of time in higher education. It frames not only the voices of researchers, as suggested by Doty (2004), but also the methods through which research is produced. (McIntosh 2015)

There is, within Hutchings' (2008) interrogation of time, a looming challenge to the role that causality plays in the wider unfolding of the history of ideas. She does not engage with the intersection of causality and social science methodologies in this particular work. What is interesting, however - and what is hinted at in the works of Hom (2010) and McIntosh (2015) - is the simultaneous rise in a particular form of knowledge. As the philosopher came to cement his role as knowledge predictor, there was, at the same time, an emerging focus on universal knowledge claims to the detriment of particular and idiosyncratic interpretations of the social and natural world. For example, Alasdair MacIntyre's (1984) interrogation of modernity provides a scathing critique of what he calls the Enlightenment Project. He demonstrates to his readers that the unfolding of history offers individuals only one side of a wider story of moral knowledge. In this work, he goes on to suggest that in seeking to achieve a rational understanding of the world, individuals have prefaced certain forms of knowledge over others. This has had a detrimental effect on the institutional design of the community. MacIntyre turns to the idea of tradition in order to re-imagine the possibilities of moral institutional design. In a similar fashion, Stephen Toulmin (1992) offers a critique of modernity and the prefacing of universal and rational knowledge that emphasises causality and empiricism. He contends that the turn to rational and universal knowledge was one path chosen to engage with social malaise over a period of 400 years.

The writings of MacIntyre (1984) and Toulmin (1992) suggest how causal findings have come to dominate knowledge production. What is more, Hutchings (2008) reflects on the agents (the philosopher) that helped this dominance come to pass. To wit, Hom (2010) and McIntosh (2015) reveal it to be a relationship that remains firmly in place within the academe, prompting academics to adopt a 
particular voice as they negotiate the demands of research and publications. I suggest that this singular influence is likewise evident in the teaching demands of the contemporary academic. Perhaps, more subtly, it also informs the way in which lecturers engage with students in their classroom. If we draw inference from the suggested development of voice by Doty (2004) and attend to the role of teaching, it is quickly apparent that the significance of teaching is cast aside. Writing in 2006, Shapiro demonstrates that teaching - and in particular scholarly teaching - is not a valued part of the tenure process. He suggests that if teaching is to become a central part of acquiring tenure, the structures of the university in particular and higher education in general must change. It is brave, he suggests, for untenured academics to build a career on teaching accolades. Should they chose to do so, it is, he writes, "at their own peril." This is an insecurity that is well documented in the academe. Kahane (2009) writes that for newly appointed faculty members - or those who have yet to obtain a permanent position - the uncertainty and lack of support in the academe, juxtaposed with the need to appear confident and in control of their classroom, can render them insecure.

Kahane (2009) documents his own experience as an untenured sessional lecturer and rehearses what it was like to acquire the protection of a permanent position at a Canadian university. He highlights the insecurity of teaching large classes as an inexperienced lecturer, and the need demonstrate to his students that he could answer any question they put to him during the lecture. He suggests that in order to attend to the vulnerability he experienced, he sought to master the canon of philosophical texts he was charged with teaching. Yet this mastery, he writes, was simply a disguise. He employed it to gloss over the wider fear of being found wanting, of being a fraud in the classroom. Kahane goes on to discuss this coping mechanism in some detail. He identifies what he calls a 'pedagogy of lack'. This approach is contrasted with what he then goes on to identify as a 'pedagogy of plenty', discussed in detail in part three. A pedagogy of lack does not contribute to a positive learning space in higher education. It masks the fear and vulnerability the lecturer feels. And it does not recognise the contributions that students can - and ought - to make in the classroom because it contributes to the silencing of the student voice so that the lecturer can dominate. Kahane (2009) reflects on his reliance on such an approach. He suggests that it was detrimental to his own conception of self while also not giving due deference to students' development. The classroom was a space within which specialist knowledge was transferred from one specialist entity to a student. There was little space for affective engagements, mindfulness or community building.

I suggest that this need to appear strong, in control and able to respond to every possible question is likewise a product of the moral efficiencies Walker (2009) discusses. Moreover, it stands in opposition to the classroom as an emancipatory space within which students and teachers can be creative, emotional and imaginative as they embrace their very subjectivities. Kahane's (2009) reflections are reminiscent of the writings of bell hooks (2010), whose works in critical 
pedagogy suggests that higher education ought to provide a space within which to query identity and understand the transformative potential of education. Such transformations are not necessarily comfortable, and will necessarily unsettle those that seek it out. Yet as Giroux (2015) has suggested, pedagogy ought to be disruptive. It demands students be critical and query the status quo in order to achieve that elusive and sought-after freedom discussed by hooks (2010). A pedagogy of lack shuts down such conversations - it does not invigorate them. I do believe, however, that this can be overcome. I suggest that narrative framings of teaching and learning that focus on stories and lived experience provide recourse for the lecturer. Narrative approaches can attend to the challenges that emerge in the face of time and mastery, which are characteristic of the modern-day teaching environment.

Narrative approaches begin with stories. Writing in 1991, Bruner provides the reader with ten archetypes of narrative. To begin with, narratives are diachronic. They account for a series of events happening over a period of time. They begin with a specific event in time, and it is this event that focuses the unfolding of the wider story. The unfolding stories may not follow a linear process and they may and most likely will - challenge iterations of clock time. Consequently, the unfolding story may never clearly adopt one singular, discernible path. Yet it is this path that can foster the transformation of the academic and student voice. This path fosters reflection. Moreover, there is space for agency. Agents can exercise their own individuality as their own autobiography unfolds. Such stories are non-linear. They emerge through the creative and emotional outlets of our selves, cater to the transformative potential of critical pedagogy and defy causal framings of clock time.

A focus on autobiography suggests an interrogative capacity. Crossely (2000) suggests that such an interrogation allows the individual to be in time rather then controlled by time. For Crossely, narrative provides a revelatory function. By telling stories and engaging with our autobiographical selves, the narrative processes reveal symbols and a wider understanding of culture within the quotidian. Much like Breuner (1991), Crossely's (2000) work hints at the possibility of narrative moving beyond structure in order to understand the subjective positioning of self in the various worlds of which we are a part. We do not live guided by time, as Hom's (2010) descriptive unfolding of western accounts of time suggests. Rather, multiple interpretations and understandings of time interweave within our daily lives. Narrative time, which is non-linear, suggests how being in time can be simultaneously transformative and elevating. It attends to the possibility of relational learning as it prompts reflexive thinking. This, I suggest, can prompt individual transformation while building a learning community. I tease out the implication of this account of time in the final section of the article.

There is value in the subjective and interpretive nature of narratives. There is a need, as Giroux (2015) argues, to disrupt the status quo. This negotiation is akin to 
the lived experience of being human. It is the act of contestation - and the meaning that emerges - that provides the ontological embeddedness of a narrative. For Bruner (1991), this might just be the ultimate strength of narrative. In essence, it outlines how to work collaboratively while probing dissonance and tension. $\mathrm{He}$ suggests that within this interrogation there is space for charity and compassion an approach that defies the logic of rights, obligations and legal representation in the resolution of struggles. Narrative openly lies in the field of contestation. Learning how to engage, while probing for deeper meanings, reveals the relational nature of our social existence and offers a mode of contestation that is critical but not confrontational. This can be uncomfortable. However, as Amsler (2011) suggests, comfortable pedagogies only enhance the status quo teaching expectations, they do not transform. The veracity of a narrative approach lies not in the expected reproduction of sought-after ends but rather in the acceptance of the story into society's wider fabric. Perhaps most importantly, the structure of the narrative provides a space within which our own autobiographies can unfold. Narrative approaches suggest an alternative understanding of knowledge creation and attend to the (potential) transformation of the academic voice in both students and lecturers.

\section{The Narrative Classroom Examined}

Telling stories reveals a voice. This voice, I suggest, is reflexive and interrogative. It is not the voice that Doty (2004) criticises. Rather, the narrative voice that emerges from within the autobiographical self is one of discovery and deeper understanding. This voice attends to lived experience and, if properly supported, prompts a deeper level of knowledge of one's self and of others. It has the potential to be transformative for all individuals within the classroom. The individuals, and in this case I refer both to the student and the lecturer, understand themselves as part of a sharing community. Elizabeth Dauphinee (2010) writes about the potential for community development within an autoethnographic experience. She suggests that such communities are neither linear nor hierarchical. What is more, they are not epistemological entities but ontological ones that foster creative knowledge production. They are, she writes, "spaces of opportunity for creation and fruitful debate that seek not to destroy the ideas and risks we might be willing to take, but instead to foster them" (817). I see, in this notion of community, many parallels to the type of community building in the classroom that hooks (2010) endorses. I draw on these two discourses in order to attend to the self-discovery that emerges in the act of telling one's story.

Autobiography, I acknowledge, is an unorthodox approach within the social sciences - although it is growing in reputation. For the most part, autobiography, as Behar (1996) writes, is situated outside the formal boundaries of knowledge creation. She suggests this is the case because autobiography, memoir and anecdotes fail to meet the expectations of causality and verifiability deemed 
important within the academy. "What bothers critics," she writes, "is the insertion of personal stories into what we have been taught to think of as the analysis of impersonal social facts. Throughout most of the twentieth century, in scholarly fields ranging from literary criticism to anthropology to law, the reigning paradigms have traditionally called for distance, objectivity, and abstraction. The worst sin was to be "to personal"' $(1996,12-13)$. Research into this methodology, however, suggests it is one vehicle for creating relationships and interconnectivity in the wider world. As Inayatullah (2010) has suggested, telling stories reveals a deeper level of connectivity with those around us. He challenges the assumption that personal revelations might alienate others. In telling his story to others, he writes, he began to witness a previously inexperienced level of shared connectivity with others. It is an idea that is similarly noted by those who use narrative techniques to address experiences of trauma. Crossely (2000) suggests telling stories provides individuals with a way of connecting their own sense of self to the wider world. Writing about those who experience trauma, she attends to the manner in which storytelling can restore a connection to a wider notion of the common good. Narrative techniques - and autobiographical storytelling in particular - situate individuals within environments that suggest the potential for positive development of communities.

The knowledge that is produced within this type of community is, by necessity, co-produced. Reflecting on this idea, Bleiker and Briggs (2010) note it requires a particular disposition on the part of the subject. The individual is the author of his or her own learning journey. They must, by necessity, "cultivate openness" with the outside world. Here I am suggesting that in the classroom we can achieve such openness - but in order to do so we must move away from the notion of students as consumers and higher education as a purchasable commodity or good. I am, in this design, suggesting that students are co-producers of knowledge. Students must, by necessity, embrace this role in order to facilitate the aforementioned transformation but also to cultivate the required relationships to support such a journey. In making this claim, I am drawing on the insights of McCulloch (2009), who suggests that understanding students as co-producers not only fosters community development but also pushes students to become active participants in the classroom. This offers students a stake in the outcomes of the community, and it consequently challenges the individualism evident in the neoliberal design of the contemporary university. The experience of higher education is transformed. It becomes a journey that fosters deep learning.

My own role as the lecturer was also transformed within this narrative setting. I remained informed by the quality demands of the QAA but I was mindful that I was not dictating the terms of knowledge dissemination. Instead, I was facilitating a journey for the students, providing them with increasing autonomy and independence as the course progressed. I took several key steps to help with this transformation. Some of these were structural and related to the planning and implementation of the module itself. Other changes attended to the QAA demands 
and subject benchmarks of politics and international relations. The final set of changes was personal and revelatory, and attended to the suggestions articulated by Briggs, Bleiker (2010) and Dauphinee (2010) - namely, I rendered my vulnerability in the teaching space explicit. I detail these changes below.

I developed two-inter-related course documents for students to help them on their learning journey. The first, a module handbook, outlined their role in the module. I was mindful that most students had not previously engaged with topics relating to political thought, nor were they accustomed to drawing on their own lived experience to inform academic narratives. Consequently, I divided the 12week module into two six-week halves. In the first half of the module, I facilitated the discussion and expected the students to come prepared to discuss the literature assigned. To help with this, the classroom space was semi-structured. The first ten minutes were a discussion recalling the previous week's discussion. This was followed by 15 minutes of creative writing on the part of the students, who reflected on these ideas and wrote down their own thoughts. This was then followed by some personal reflection sharing, which dovetailed into the new weekly discussions. The module handbook described these structural expectations while providing key readings on both political theory and narrative methodologies. I hoped that these documents would enable students to prepare for class aware of the authors and narratives under discussion. More importantly, I hoped they would facilitate the development of trust within the classroom. Trust, I suggest, is necessary if students are to feel secure and render themselves vulnerable by sharing their lived experience honestly and openly.

To support reflexive thinking alongside a critical interrogation of contemporary political theory narratives, I aligned the assessments with the learning outcomes. Students were required to demonstrate in their submissions a reflexive - and necessarily subjective - framework. They were required to submit one reflexive piece of writing that engaged with core works of political theory. They were also expected to collaborate within a group to prepare and lead one two-hour seminar, concluding with a second reflexive submission. This submission reflected on the nature of the presentation, the use of formal and informal feedback and the transformative nature of the presentation experience itself. The first submission was completed in week six. The second submission was submitted after the winter break to allow greater time to practise and produce reflexive thinking.

The value of this alternative knowledge production is clear. This approach demands attention to excluded forms of knowledge. The pursuit of this approach facilitates transformative experiences but does so at the expense of efficiency and exchange value - ideas that are aligned to the institutional identity of neoliberal university designs. As hooks (2010) writes, it prompts a critical and engaged ethos among students, sustaining their critical abilities well beyond the university experience. However, it is not the status quo methodology training that students tend to receive. Consequently, students worry about the grade they will receive and if they might fail. They are rendered insecure throughout this process. While this 
insecurity is an important experience of the reflexive process, it must be attended to and supported appropriately.

In order to attend to this revelation, I developed - alongside the module handbook - an assessment handbook that detailed the nature of the assignments, provided key literature on how to write within a subjective and narrative approach and outlined the assessment criteria and process. I also made myself available to students beyond the classroom and traditional office hours. I built time into the learning hours, outside of my assigned teaching hours, to meet with these final year modules and attend to their creative engagements within the module. For the presentation, students were offered small group tutorials of three to four students to work through the seminar. Within this group, students were offered the opportunity to negotiate their assigned texts, interrogating the wider messages while attending to the challenge of reporting them to their fellow classmates. Summative feedback was also offered on the structure and content of the presentation itself, in order to ensure that the information aligned with both the assessment criteria and the module's learning outcomes. Informal learning opportunities extended beyond this small group tutorial. Students routinely sought me ought to work on their own written submissions as well. Students struggled to understand what their 'voice' might be and how to represent it on the page. Having been trained to produce works of an empirical nature and seek out the social scientist within them, it was hard to unlearn this approach. Much time was spent in these lessons interrogating students' learning journey and understanding how to represent this on the written page.

For these structural changes to have any impact, I also had to learn how to present myself openly and honestly. If I could not enact that very vulnerability and openness I was demanding of my students, the relational learning could not begin nor, I believed, would students accept my authenticity within an autoethnographic experience. Consequently, I had to surrender the traditional power bestowed on the lecturer in the classroom while presenting an honest account of who I was. I had to reveal the multiple identities, stories and lived experiences that informed who I was and what I wanted to encourage my students to become. While I relied quite heavily on the idea of authenticity to reveal my pedagogical approach, authenticity is a challenge to autoethnographic methods; indeed, the idea of authenticity itself can be troubling. Jones et al. (2012) suggest in their study of identity and intersectionality in higher education that authenticity is difficult to achieve when deciding which personality to present to the audience. What is more, they note that identity can be fluid and multidimensional, consequently what may or may not be authentic depends on the time and location of the engagement. However, I knew that to connect with the students I had to provide insight into my teaching approach, which was relational, multilateral and premised on the building of personal relationships. To allow for this to develop, the stories I used to inform the political theory narrative drew on my own experiences of being a student, mother 
and researcher, but also my newly discovered scepticism in the social justice narrative - itself under examination in this particular module.

\section{Reflexivity, Transformation \& Autobiographical Time}

Autoethnographic learning - informed by an autobiographical interrogation of self and academic discourse - can be transformative. As Starr (2010) has written, autoethnography can be simultaneously critical and transformative as a pedagogical tool. She draws on autoethnographic approaches in order to query identity and privilege in multicultural countries, specifically Canada. She notes that within Canada the multicultural heritage is not reflected by those engaged in the practice of teaching. She suggests that an autoethnographic interrogation of teaching practices can reveal subtle assumptions about race, identity and privilege, which - if suitably supported - can transform the learning environment. I suggest, tangentially, that it is this reflexive interrogation that my students were embarking upon during our informal meetings and within the classroom. Transformative learning suggests a change on those involved in the learning process. As Markos and McWhinney (2003) suggest, transformative education involves a degree of introspection on the self prompted by significant changes in lived experience. They suggest that such transformations begin "when a person withdraws from the world of established goals to unlearn, reorient, and choose a fresh path" (16). When Kahane (2009) writes of his use of mindful techniques and his adoption of a pedagogy of plenty, he notes, in his narrative feedback from students, that many of his students experienced this type of re-orientation.

My own feedback within the module reflection forms revealed a similar type of transformation in the ideas, opinions and understandings of self within the classroom. Aston University's module reflection forms ask students to rate the lecturer using a scale of 1-5 on a series of pedagogical and stylistic experiences in the class. This is followed up with a space to reflect on the course, prompted by a series of questions. Students were asked to comment on what they enjoyed and what could be improved, and to provide any additional comments they felt necessary. The responses reflected on many of the changes discussed in both section one and two. For example, students described the flipped lecture style along with the classroom layout and the topics covered - as being things that stood out. One student commented on the reflexive nature of the assessments, suggesting they challenged his worldview and prompted deeper reflection on his part. The notion of lived experience also stood out for students. They commented on how it helped challenge assumptions and provide innovative alternatives to their authenticity as students and their positionality in the world. This feedback was insightful. It revealed fear of the unknown, of not having engaged with reflexive learning styles. There was also fear of doing the work 'wrong'. But, interestingly, the students recognised the value of being pushed to reflect and build on their own lived experience to generate both personal and academic insights. 
This introspection defies the causality evidenced in social science methods. To reflect, and in turn, narrate, our lived experience does not align with the outcomes of a social science methodology. Our lived experiences and the stories that they generate defy the linearity of time that authors such as Hutchings (2008), Hom (2010) and McIntosh (2015) have queried. While a singular concept of time, such as linear time, might order the various stories that suggest a person's identity and temporal subjectivity, autobiographical storytelling bifurcates such linearity. To remember a story is to recall a past event, yet this storying is happening in the present. What is more, as Brockmeier (2000) points out, even if we are living our lives and telling our stories in the present, we are constantly living with an eye to the future. He is concerned with the various ways time reveals itself in the unfolding autobiographical narrative. Reading his work, it becomes clear that time features in a variety of way as individuals decide how to author their stories. A focus on authorship reveals some interesting questions. For example, how will a particular plot line in our lived experience unfold, and what impact will that have on the path we then follow? What is more, lives are generally informed by certain expectations of the future. How those expectations impact on our unfolding futures will not only impact what the present story will become, but will also affect how we reflect on the story once it has become a memory. The future interpretation of that memory will have an impact on the remembered present. Thus, it is deeply problematic to suggest that autobiographical reflections can be related to the causal inferences evidenced in a scientific methodology. Autobiographical time, unlike clock time, is unpredictable and open to alternative endings during the storying process.

The unfolding autobiographical reflections inform reflexive knowledge creation. Reflexive thinking suggests a space within which the process of storying and re-storying lived experiences can unfold, making space for information that may or may not have been relevant during the story's first telling. Reflexive thinking allows authors to re-story their lived experience. It facilitates the inclusion of otherwise unexpected information. In their work on reflexive thinking, Ackerley and True (2008) suggest that this type of reflexive thinking is beneficial to research design. They write of the process of research design and knowledge creation and what to do when the information gathered does not fit with a project's intended outcomes or desired conclusions. The transformative potential of reflexive research and teaching is likewise noted by Wilkinson (2013), who suggests that probing the dissonance that emerges in the face of unexpected results - while uncomfortable reveals unexpected opportunities and insights into "the nature and politics of knowledge production" (403).

As Epston and White (1990) suggest in their work on narrative therapy, restorying - as part of a reflexive process - allows individuals the opportunity to author and re-author their stories on their own terms. White and Epston suggest that narrating our lived experiences provides individuals with a way of making sense of their temporality and positionality in the world. Through a process of 
reflection, interrogation and restoration, individuals come to understand the story on their own terms, making use of previously unacknowledged or unknown facts of the story. This idea is likewise articulated by Crossely (2000). She suggests that storytelling is a way of being in time and a method of re-situating the self in the relationships and communities we want to be a part of. However, what emerges from this reflexive process is that the stories - and their excavation - are nonlinear. This type of knowledge creation relies not only on personal narrative but also on time-lapsed revelations. In telling one's story, the individual memory work combines flashbacks and flash-forwards. The rate of progression is determined by the author's ability to negotiate and assimilate secondary information. Much like Bruckmeier's (2000) articulation of a retrospective teleology, this re-authoring is neither predictable nor controllable.

I suggest that within this storying process alternative skills development occurs. These skills are central to the transformative process: namely, critical reflection, empathy and engaged citizenship (to name but a few). This skill set stands at odds with the notion of moral efficiency discussed by Walker (2009), and might be interpreted as a challenge to the mastery identified by Hom (2010) and McIntosh (2015). However, if the philosopher enjoys the prominent and influential position that Hutchings (2008) describes, then this criticality is a much-needed antidote to the individualism and insular ideals of neoliberal institutional design. The aforementioned skills foster community development like that articulated by Dauphinee (2010) and hooks (2010), and this community is a vital component of the narrative experience. It provides the audience and teaches individuals how to listen. Listening, I suggest, is central to reflexivity and the authoring of stories. As Giani writes, listening is a relational experience. She notes: "in order to be able to listen to the other person you have to listen to yourself" (77). Listening, then, is both a workout and a training process. It exposes the individual to greater possibilities and experiences. "This is because," she goes on to suggest, "it is the other person and the multiple everyday contexts (both formal and informal) that provide a great deal of questions, problems, queries and emotions that tell us something about ourselves" (77). Listening - and being attuned to its relational expectations - is an equally important part of the reflexive process. I suggest that in listening to the stories of others, we, as an audience, become central to the restoring process and provide the structural support within which uncertainty can be probed.

Reflexive work is a fearful work, as it demands a level of introspection about who we are and what we do. Consequently, the listening that occurs within this community must transcend the privilege and asymmetries of power that typically structure the classroom. Thompson (2003) attends to the challenges of reciprocal listening. She writes that accepted forms of listening have moral criteria that seek to ensure all individuals are all included, no one is left with a bad feelings and no one is blamed. This, she suggests, is problematic. A radical account of listening, she concludes, can be transformative if it acknowledges the multiple vulnerabilities that each individual carries and starts from a position of empathy and recognition. 
Radical listening involves all members of the community presenting an authentic account of themselves. The added benefit of this presentation of the self is the emergence of the community. This radicality is likewise discussed by hooks (2010). She writes: "Hearing one another's personal experience in the classroom promotes an atmosphere of cooperation and deep listening. Ultimately, the negative possibilities that can arise when teachers validate the sharing of personal experience are small compared to the positive rewards when such sharing helps create a community of learning and enhances ways of knowing" (58).

I suggest that such a transformative can be achieved within the space of the narrative classroom. Lecturers must attend to the various imbalances of power and listen to what their students are conveying in their stories. It is within these disclosures that vulnerabilities emerge and reflexive practices can be sustained. In seeking to practise radical listening and identify the creative voice of transformation, it is possible to create a wider, holistic learning environment.

\section{Conclusion}

I have suggested that narrative approaches to learning and teaching can slow down our professional practice and attend to the wider pastoral needs of our student populations. I hope to have shown that my own experiences in framing a classroom in this particular way, - drawing on autoethnographic methodologies, prompts reflexive thinking. This, I argue, allows students and lecturers to re-imagine themselves as part of a learning journey and co-producers of knowledge therein. Implicit within this claim is the idea that autobiographical (or narrative) time must by necessity slow down the learning process. There is much to be said about the outcomes of this approach. It is transformative for all involved in the learning journey. The reflexivity demanded of storytelling and the authenticity it requires from all involved fosters new and interesting ways of attending to the world. It highlights the multiple roles we all play in the ongoing design of our communities, and the need to attend to the multiple vulnerabilities and expectations that individuals carry with them. This approach has much to say about the potential within higher education to developed engaged and active citizens beyond the formal classroom experience.

There remains much to be said about this particular approach. We must begin to imagine how to embed this approach further in the institutional structures of higher education. Similarly, we must remain aware of the challenges of scepticism and mistrust that will emerge from within communities. For example, students must unlearn the individualism that sustains subject mastery and the learning that focuses on the moral efficiencies of clock time. This is hard work, and as Amsler's (2011) research demonstrates, it is work that not all students will embrace. It will take time and patience, and not all students will relish the reflexive challenges articulated throughout this article. Rather then shy way from this challenge, I draw strength from hooks (2010), who suggests that such students only push her to think 
of more creative and imaginative ways of engaging students in learning. We must heed this advice.

There is also a potential for a similar challenge from colleagues who fear the hard work of reflexivity. Those who embrace the call to attend to a slower, narrative approach may experience a marginalised position within the community. Rather then walk away from this experience, I suggest it be embraced and absorbed. Drawing on what Giroux (2016) has called the exiled academic, I suggest that this approach has much to offer those that seek to challenge status quo iterations of neoliberal framings of higher education. Giroux writes: "Less an oppressive space of containment and deskilling, exile can become the grounds for a revitalized kind of public space and activism where a new language, a new understanding of politics, and new forms of solidarity can be nurtured among the displaced - that is, among those who refuse the neoliberal machinery of social and political violence that defines education solely as a source of profit, mode of commerce, and 'feel good' pedagogy."

A narrative framing of the classroom has the potential to disrupt the status quo. Moreover, it has the capacity to re-ignite an imaginative and personal form of knowledge creation that begins - but does not stop - in the classroom. I suggest that one happy consequence of this approach is the slowing down of the learning journey and the flourishing of genuine relationships premised on empathy, criticality and transformation.

\section{NOTE}

1. Institutional design in this context references the work of Robert E. Goodin. He suggests a minimalist definition of institutions. They are, he writes, "the stable, recurring, repetitive, patterned nature of the behavior that occurs within institutions, and because of them" (22). See Goodin, R. E. 1998. The theory of institutional design. Cambridge: Cambridge University Press.

\section{REFERENCES}

Ackerly, B., and True, J. (2008). Reflexivity in practice: Power and ethics in feminist research on international relations. International Studies Review, 10(4), 693-707.

Amsler, S. S. (2011). From 'therapeutic' to political education: The centrality of affective sensibility in critical pedagogy. Critical Studies in Education, 52(1), 47-63.

Behar, R. (1996). The vulnerable observer: Anthropology that breaks your heart. Boston, MA: Beacon.

bell hooks (2010). Teaching critical thinking: Practical wisdom. New York: Routledge.

Brigg, M., and Bleiker, R. (2010). Autoethnographic international relations: Exploring the self as a source of knowledge. Review of International Studies, 36(3), 779-798.

Brockmeier, J. (2000). Autobiographical time. Narrative Inquiry, 10(1), 51-73.

Bruner, J. (1991). The narrative construction of reality. Critical Inquiry, 18(1), 1-21.

Chambliss, D. F. (2014). How college works. Cambridge, MA: Harvard University Press. 
Crossley, M.L. (2000). Narrative psychology, trauma and the study of self/identity. Theory \& Psychology, 10(4), 527-546.

Dauphinee, E., (2010). The ethics of autoethnography. Review of International Studies, 36(3), 799-818.

Doty, R. L. (2004). Maladies of our souls: Identity and voice in the writing of academic international relations. Cambridge Review of International Affairs, 17(2), 377-392.

Giani, A. (2014). Reflexivity is listening. In M. F. Freda (ed.), Reflexivity in higher education (pp. 71-80). Roma: ARACNE.

Giroux, H. A. (2016). Exile as a space of disruption in the academy. Available on http://miietl.mcmaster.ca/site/exile-as-a-space-of-disruption-in-the-academy/. Accessed 13 May 2016.

Giroux, H. A. (2015). Higher education and the politics of disruption. Available on: http://www.truth-out.org/news/item/29693-higher-education-and-the-politics-ofdisruption. Accessed 10 May 2016.

Giroux, H. A. (2002). Neoliberalism, corporate culture and the promise of higher education: The university as a democratic public sphere. Harvard Educational Review, 72(4), 425464.

Goodin, R. E. (1998). The theory of institutional design. Cambridge: Cambridge University Press.

Hayes, S., and Jandrić, P. (2014). Who is really in charge of contemporary education? People and technologies in, against and beyond the neoliberal university. Open Review of Educational Research, 1(1), 193-210.

Hom, A. R. (2010). Hegemonic metronome: The ascendancy of western standard time. Review of International Studies, 36(4), 1145-1170.

Hutchings, K. (2008). Time and world politics: Thinking the present. Manchester: Manchester University Press.

Inayatullah, N. (ed.) (2010). Autobiographical international relations: I, IR. New York: Routledge.

Jones, S. R., Kim, Y. C., and Skendall, K. C. (2012). (Re-)framing authenticity: Considering multiple social identities using autoethnographic and intersectional approaches. The Journal of Higher Education, 83(5), 698-724.

Kahane, D. (2009). Learning about obligation, compassion, and global justice: The place of contemplative pedagogy. New Directions for Teaching and Learning, 118, 49-60.

Lynch, K., Lyons, M., and Cantillon, S., (2007). Breaking silence: Educating citizens for love, care and solidarity. International Studies in Sociology of Education, 17(1/2), 1-19.

Lynch, K. (2006). Neo-liberalism and marketisation: The implications for higher education. European Educational Research Journal, 5(1), 1-17.

MacIntyre, A. (1984). After virtue: A study in moral theory. Notre Dame, IN: University of Notre Dame Press.

McWhinney, W., and Markos, L. (2003). Transformative education across the threshold. Journal of Transformative Education, 1(1), 16-37.

McCulloch, A. (2009). The student as co-producer: Learning from public administration about the student-university relationship. Studies in Higher Education, 34(2), 171-183.

McIntosh, C. (2015). Theory across time: The privileging of time-less theory in international relations. International Theory, 7(3), 464-500.

Patrick, F. (2013). Neoliberalism, the knowledge economy, and the learner: Challenging the inevitability of the commodified self as an outcome of education. ISRN Education, 108705. 
Shapiro, H. N. (2006). Promotion \& tenure \& the scholarship of teaching \& learning. Change, 38(2), 38-43.

Sloan, K. (2008). The expanding educational services sector: Neoliberalism and the corporatization of curriculum at the local level in the US. Journal of Curriculum Studies, 40(5), 555-578.

Starr, L. J. (2010). The use of autoethnography in educational research: Locating who we are in what we do. CJNSE/RCJCÉ, 3(1), 1-9.

Taylor, E. W., and Cranton, P. (2012). The handbook of transformative learning: Theory, research, and practice. San Francisco, CA: Jossey-Bass.

Thompson, A. (2003). Listening and its asymmetries. Curriculum Inquiry, 33(1), 79-100.

Todd, M. J., Smith, K., and Bannister, P. (2006). Supervising a social science undergraduate dissertation: Staff experiences and perceptions. Teaching in Higher Education, 11(2), 161-173.

Toulmin, S. E., and Toulmin, S. (1992). Cosmopolis: The hidden agenda of modernity. Chicago, IL: University of Chicago Press.

Urry, J. (1994). Time, leisure and social identity. Time \& Society, 3(2), 131-149.

Walker, J. (2009). Time as the fourth dimension in the globalization of higher education. The Journal of Higher Education, 80(5), 483-509.

White, M., and Epston, D. (1990). Narrative means to therapeutic ends. New York: Norton.

Wilkinson, C. (2013). Not just finding what you (thought you) were looking for: Reflections on fieldwork data and theory. In D. Yanow and P. Schwartz-Shea (Eds.), Interpretation and Method: Empirical Research Methods and the Interpretive Turn (pp. 387-405). $2^{\text {nd }}$ edn. Armonk, NY: M.E. Sharpe.

Amanda Russell Beattie is a Lecturer in Politics and International Relations at Aston University. Amanda's area of research is situated at the intersection of ethics and global affairs. Previous research reflected a commitment to cosmopolitan iterations of the world. Personal experiences with the UK deportation regime challenged this world view prompting an interest in narrative theories informing an ethical iteration of the global world. Within this research she remains critical of the privileged role of the academic in the production and dissemination of knowledge that likewise informs her interest in teaching and learning, transformative pedagogies and developing the idea of the "narrative classroom'. 